\title{
POLISH, ROMISH, IRISH: \\ THE IRISH TRANSLATION OF QUO VADIS?
}

\author{
ALAN TITLEY
}

\section{Translations into Irish, their background and history ${ }^{1}$}

It is said that when an Irish Taoiseach, or Prime Minister, visited Tokyo some years ago he referred to 'the close cultural ties between Ireland and Japan.' It does seem just like the kind of thing that a civil servant would write for his boss. There are, of course, some cultural ties between Ireland and Poland, but we should not exaggerate them. During the height of literary translation into Irish in the 1920s, 30s and 40s, I can only think of two Polish books that were translated into Irish. Many of the novels of Joseph Conrad were indeed translated by the Donegal writer Seosamh Mac Grianna, but Conrad can often be labelled as an English author, at least from a linguistic point of view. The two books that were originally written in Polish and rendered into Irish were not translated directly; one of them was translated via French, and the other via English.

The first of these is the quite famous Leabhar na Polainne, or 'The Books of the Polish Nation', by Adam Mickiewicz, translated by Liam Ó Rinn, a cosmopolitan author who also wrote the Irish words of the national anthem. The story of this translation is itself quite fascinating, as it was done through a French translation, and was intended to draw analogies between the Polish and the Irish struggles for independence; this translation is currently being studied by Mark Ó Fionnáin of the Catholic University of Lublin, and does not form part of the concern of the present paper.

The other translation is Henryk Sienkiewicz's famous Quo Vadis?, which helped him secure the Nobel Prize for Literature, and which has been translated into numerous languages, and made into several films or series of films for television. It was translated into Irish by An tAthair, or Fr. Aindrias Ó Céileachair (1883-1954) in 1935. It was translated from the English, which in itself is a story that bears investigating. The background to this translation is a project instigated by the Irish state a few years after independence, and which sought to provide much reading material for the new Irish-reading public which they were beginning to create. The scheme is generally known as 'An Gúm', which is

\footnotetext{
${ }^{1}$ I am grateful to Dr Seán Ua Súilleabháin who provided me with a copy of the translation of Quo Vadis? on which this article is based, and who educated me on many points of the West Cork dialect with which I was not familiar.
} 
simply a dialectical word for 'scheme', and did manage to provide a wide-range of books for the public within a short number of years (Uí Laighléis 2007). A great deal of these books were translations, as indeed must needs be the case in any minor or less-widely used language.

A great many of the classics of world literature were translated into Irish as a result of this project. Many other translations were done before this scheme, and others after it, both as forerunners and as further exemplars. So, for a reasonably small language like Irish, it is remarkable that we have novels, apart from potboilers and contemporary bestsellers, like Don Quixote (although the translation is suitably quixotic), David Copperfield, Robinson Crusoe, The Hound of the Baskervilles, Dracula, four versions of Alice in Wonderland as well as stories by Chekhov, Tolstoy, Turgenev, Daudet, de Maupassant, plays by Shakespeare, Moliere, Aeschylus, and world classics like The Odyssey, The Divine Comedy, some of Plato's dialogues (Apologia, Crito, Phaedo), Augustine's Confessions - indeed, it is possible to be widely read in the literature of much of the world if you only spoke or read Irish.

Some of these translations are brilliant, and some of them are truly awful. The reason for the discrepancy in standard was because the state publishing company had no stated policy on how translations should be conducted. They trained nobody, and neither did they give advice. As a result of this, translators could do more or less what they wished, provide they came up with the goods, or the bads, as they often did. The editors were far more interested in the production of good idiomatic Irish than in the faithfulness of the translation. In translationstudy terms, the target language was the god, not the source-language. The source language was merely an excuse to allow the translator to indulge himself. And some of them did just this.

Many writers shortened their texts if they encountered difficulties, but Máirtín Ó Cadhain, the famous Irish prose writer of the twentieth century returned a translation of Charles J. Kickham's Sally Cavanagh which was almost twice as long as the original. Another writer, Seán Tóibín, avoided mention of any part of the body that might suggest that the possibility of sex existed, so that a kiss became a look, and children were begotten by some kind of miraculous conception. Most of these translators were native speakers of Irish and wrote freely in their own dialects before the onset of any real standardisation, so that many of these books are not only a pleasure to read for their intrinsic qualities and for the freedom with language that the authors took, but also for linguists interested in the study of Irish dialects, in particular Irish dialects with an educated twist. 


\section{The story of Aindrias Ó Céileachair, Irish translator of Quo Vadis}

This educated twist becomes more important in the case of our translator of Quo Vadis. He was born Aindrias Ó Céileachair, the son of a small farmer and his wife, in the strong Irish-speaking district of West Cork. What is unusual is that he went on for the priesthood, and was the first priest who came from his district for several generations. This is because the priestly class was most often drawn from people who were better off than the simple peasantry. It took a higher superstition and more money to become a priest. We have some proof that despite his education he was still hesitant in English even as a young priest. He also had a scholarly disposition.

He studied Irish in Maynooth College and edited a poem for the journal Ériu. There was talk of sending him on the foreign missions, but during one summer he read through Thurneysen's Grammar of Old Irish. This seems to have been a reverse conversion, and the only example of Thurneysen frightening somebody from the mission fields. The scholar Gertrude Schoepperle thought very highly of him, saying that he could read old Irish texts by sight. He applied for a position of lecturer in Irish in UCD, but for some reason this position was never filled. He was sent as a priest to Liverpool, but taught Irish in the university there as well. He received a scholarship to the University of Illinois, and while he was there he edited Betha Coluim Cille with Gertrude Schoepperle.

This scholarly background is relevant, because although many of the translators that worked for An Gúm were highly educated, very few of them had the university training and background, and particularly in Celtic Studies, which he had. In this sense he is quite exceptional. It seems that he quite gave up on scholarship early on, and spent the rest of his working life as a teacher in diocesan schools in parts of Cork. While he was in one of these schools he received a letter from the Secretary of the Publications Committee of An Gúm inviting him to partake in the scheme to write either an original book or to translate one. This letter, of 19 July 1928, does not tell us why they wrote to him in particular dubhradh liom sgríobhadh chugat, 'I was told to write to you' - and it does not suggest any particular book, or kind of book to him. This freedom of choice was the common practice, allowing translators sufficient freedom for them to exploit or abuse.

It took him some months to reply as he was on holidays at the time. When he does so in early November 1928, he says he would be happy to participate in the scheme, and mentions that he has already been working on an Irish translation of Macbeth, probably unaware that one had already been published two years previously in 1926. It was entirely appropriate that Macbeth would be translated into Irish, as this was the language that the historical king spoke, before he was dastardly murdered by pretentious upstarts who eventually made way for the disastrous and rotten Stuarts. Apart from this reference to the Scottish play, he 
does hint that he would prefer to do something 'literary' or 'historical', and we must presume that it is out of this preference, as well as its obvious Christian subject-matter, that he decided to undertake the translation of Quo Vadis.

Less than three weeks later, on 12 December 1928 he sent them the first chapter. This first chapter was always seen as a sample chapter, a kind of test, to see if the translator was up to the job. A few days later their chief reader, the formidable Pádraig Ó Siochfhradha, who was one of the sharpest, most severe, and most demanding of editors, wrote back promptly - Tá an sompla so ar fheabhas, 'This example is excellent, tell him to continue and finish the job'.

This is what he did. Unfortunately, there is often a catch in these matters as the course of true translation never runs smoothly. When he had finished the job, it was discovered that he had been working on an abridged version of the book and not on the complete version. The fact that he was providing a shortened version was copped on to by the same Pádraig Ó Siochfhradha (1883-1964) in a letter of May 1929. Ó Siochfhradha's pen name was An Seabhac or 'The Hawk', a name which he chose himself, but which certainly fitted him because of his beady eye. He initially presumed that Ó Céileachair was taking upon himself to abridge the novel, as this was a common enough practice.

He asked the editors if they were going to be happy with the chopped-off circumcised version, and reminding them that it might not be a good idea to repeat the example of the translation of Don Quixote, by another priest, Fr Peter O'Leary, many years before. O'Leary's translation amounts to about one tenth of the whole; he turns the Don and Sancho Panza into farmers from the west of Ireland, and similarly avoids any mention of the more robust and Rabelaisian humour that the original contains. In one famous scene of the original a serving girl is trying to climb over Don Quixote in order to get to the bed of another traveller; O'Leary turns this into a situation where she is actually looking for a barrel of wine, giving arise to the belief that sex was a far more pernicious sin in nineteenth century Ireland than booze in sixteenth century Spain. There is, indeed, a school of thought which believes that shortening a book is tantamount to improving it, and few would argue that any of Jane Austen's novels would not have been hugely entranced by the joyful use of a scissors, or a billhook, or by the employment of any slashing agricultural instrument.

It turned out that the version that Ó Céileachair had been working on was only 250 pages long, while the fuller version was more than 450 . He complained that the translation he had completed could be published immediately if they so wished it, but his editors insisted on the full unclipped version. He tried for a while to add the missing bits in a primitive cutting and pasting operation, but finally decided that it would be easier to start again. This he apparently did. A short handwritten note in a letter sent to him in July 1929 regretting the extra 
work they were putting on him urges that he be reminded to complete the work ‘as quickly as possible’.

This, however, was not done. While he completed the shortened book in about six months, it appears that the longer work took him nearly five years. There were several reasons for this. The first appeared to be bad health, as he began to suffer from severe arthritis around this time. The second, however, is more interesting. Much of my argument here is mere surmise, where surmise is the compliment that imagination gives to the holes in scholarship. On the other hand, it is based on his method of translation. He decided to take much more pains over the new work than he had done originally and to seek the help of some of the best Irish speakers of his own area in the process.

\section{3. Ó Céileachair's approach to translation}

Translators of fiction into Irish in the late nineteenth and in the first half of the twentieth century had many obstacles to overcome. The most obvious one being that the language had not been used as a vehicle for original imaginative fiction for hundreds of years, and that it often lacked the easy vocabulary of an urban setting. Thus, it was easy enough to translate the execrable novels of Charles $\mathrm{J}$. Kickham in their rural setting, or the stories of Canon Sheehan, both popular novelists in Ireland for reasons which have baffled the best brains of the country. But to translate work which involved different registers of language, in a foreign setting, with exotic peoples, and through an arcane vocabulary, using technical words which had never penetrated the Irish lexicon, was a much more challenging task.

Linguistic matters and the range of lexicon are of great importance, but primacy in literature must always be given to matters of feeling. How does a language translate the matter of the world and society on to the page? How does it echo and taste and touch? I have no idea how Sienkiewicz manages to bring the matter and feeling of Rome into Polish. We know that his characters spoke Latin. And Latin has always been a language of the sun, a language which is clear and lambent and bright; a language cold in its carved letters, unambiguous as a massacre, plangent as an empire. Latin is written on these big blocks of stone, where no line wavers, where chiselled meaning is not subject to debate. Latin is the serried ranks of Roman soldiers in their blockish phalanxes ready to crush any stray being who wanders from the united centre. I have no way of knowing how Quo Vadis feels its way through Rome in Polish. At least the sun shines in Polish in a way that it cannot do in Irish. Irish is not a sunny language. It is wet, and mucky and messy. It is a language of bad weather and clouds and rain. If you want confirmation of this it is sufficient to look at Lambert McKenna's EnglishIrish Dictionary (1935: 1061-1062). He devotes four and a half tight columns to words and expressions on rain; while less than half a column shines on the sun. 
The challenge is, therefore, not just to translate the English translation of a Polish translation of Roman life into Irish, it is to make it credible.

So what then does Ó Céileachair do? He uses his own native West Cork Irish as a base. He retains Latin words throughout the text for untranslatable items tepidarium, frigidarium, tablinium, unctorium, velarium, impluvium, spandium and some of these he explains, but more usually does not. This follows the example of the translation he was using. He introduces archaisms from Irish. He uses words that he would have been acquainted with in his own scholarship from learned tales or documents, and which people with a vague acquaintance with the literary language would be familiar with: ar cheana 'but however', ciodh trácht 'as it goes', iomthúsa 'as regarding', gidh eadh 'be as it may', iar bhfíor 'as it happens', etc.

More significantly, he employed the advice of one of the greatest storytellers and bearers of traditional lore from his own area, Amhlaoibh Ó Loingsigh (1872-1947), and it appears that he discussed and debated every sentence in his translation with him. The editor of Ó Loingsigh's stories and tales credits him with the translation just as much as Ó Céileachair. It is not difficult to see why. It should also be said that Amhlaoibh Ó Loingsigh was the main informant of Professor Brian Ó Cuív for his study of this dialect, The Irish of West Muskerry (Ó Cuív 1944). Ó Cuív describes him in the introduction as "a very careful speaker... a well-known seanchaí, and has won many prizes at feiseanna and at An tOireachtas” (Irish cultural festivals) (Ó Cuív 1944: x).

In the collected tales of this storyteller, the editor, Donncha Ó Cróinín, says that he uses phrases and locutions and turns of talk in Irish, that will never be heard again. He is implying, of course, that Ó Loingsigh was a conservative speaker, and that he was a conservative speaker because he was carrying around in his head stories and tales which were ancient, and which still retained some of their archaic dressing.

These conservative uses are entirely echoed in the translation of Quo Vadis. Many of these consist of the use of the genitive case 'in clusters', where the more accepted modern usage would be to use the nominative. Thus: d'fhonn tuairisce an leinbh do chur 'for to ask for an account of the child', ag iarraidh an scéil a réiteach 'to try to solve the question', toisc a mhíthreoire féin 'because of his own misdirection', 'fé dhéin cúirte an impire 'towards the court of the emperor', de chionn coire éigin 'because of some crime', toiltheanach chun báis a fháil 'happy to die', chun cuimhnimh air 'to think of him', ar son airgid d'fháil uaim 'to get money from me', and more and more and more. But this is just one example of an 
archaic usage which had survived in speech, and particularly in the speech of a storyteller.

Conservative uses of the adjective in the genitive plural abound throughout the text, and while remnants of this usage still exist, particularly in the classical Irish of West Cork, they cannot be said to be common: ag ithe pónairí dtirim 'eating dry beans', ag íobairt colún mbán 'sacrificing white doves', i dtaobh gabháltas mbeag 'as regards a small holding', ar ardú a shúl ndonn 'lifting his brown eyes', i dteannta na n-aislingí mbreátha 'along with the fine dreams', ag caitheamh brat n-ioldathach 'wearing the multicoloured cloaks', fáscadh na lámh bhféithleogach 'the tightening of the sinewy hands', a lán ainnear n-álainn 'a lot of beautiful young women', i measc na gcúlsráideann ngránna 'throughout the ugly backstreets', a lan carbad ngreanta 'a lot of decorated chariots', and more that can become quite infectious.

These usages have a certain beauty, and I like to retain some of them myself in my less standardised moments, but they are not likely to grow in popularity in contemporary Irish.

They do, however, have a general effect. They are signalling that he is using a noble form of Irish, an Irish that is removed from the ordinary concerns of the poor people among whom he lived, an Irish through which the ancient world could come alive.

Apart from his constant discussions with this eminent story-teller, there is evidence also that he consulted everybody he met along the way, or on the road, or in field or farm in his native area, and would ask them how they would put Irish on any particular phrase. Thus, there is a sense in which this translation is entirely a community effort, in which An tAthair Andy, as he was commonly known, enlisted the assistance of everybody; and we can argue that as Quo Vadis is a novel rich with characters from every walk of life, that he was able to bring all these registers to bear on his and on his community's translation.

This collaborative effort is not dissimilar to the work of another Catholic priest, An Monsignor Pádraig de Brún - an even more learned graced eminence than Fr Ó Céileachair - who translated the Odyssey and The Divine Comedy into Irish. He used to labour on his translations during the day in the house which he owned in the Kerry Gaeltacht, or Irish-speaking area, and these translations were done from the original classical Greek and from Dante's Italian. And then, probably for light relief, he would call in some of the men of the area, and they would spend the night in light carouse and chatter. These were the best and most highly-thought of story-tellers and poets, and they would examine what he had written and suggest ways of putting what he had done into better, more accurate 
and more appropriate Irish. The result is two of the finest pieces of writing that we have in Modern Irish. A further result was that parts of what he had translated found their way back into local lore and local verse. What we call higher literature and folk literature can always support and enrich one another, as these examples show.

\section{Further Irish connections with Quo Vadis: The story of Jeremiah Curtin}

If we look for further Irish connections with the novel, we may have a hard task. We must assume that Ó Céileachair chose Quo Vadis, being a Catholic priest, and therefore being emotionally close to a novel which depicts the rottenness of Rome, the perfidy of Nero and the beauty and love of Christianity. For those interested in trivia, there are two mentions of Ireland in the book, both of them referring to the getting of wild dogs from Hibernia, all the better for to eat the entrails of the Christians. But there is another connection beyond this which is not insignificant.

The official translator of Quo Vadis in English, the translation which had the blessing of Henryk Sienkiewicz himself, was done by Jeremiah Curtin (18351906), an Irish-American first-generation scholar and folklorist. Curtin himself learned Irish, along with many other languages, although there is a dispute as to his actual competence in both Irish and Polish. He collected tales and folklore from storytellers as eminent as Amhlaoibh Ó Loingsigh, albeit from a generation one knee younger, and is often recognised as the first genuine collector of folktales in Ireland.

Jeremian Curtin is himself a fascinating character. He was born near Detroit in Michigan in the United States to parents who had emigrated from Ireland just before the great famine. They acquired land recently stolen from the native population, but there still were enough of them around unsculled and unscattered for Jeremiah to acquire some of the Indian languages as a boy. He also learned some German, a smattering of Norwegian and certainly heard both Polish and Irish around him while growing up. At some stage in his youth and childhood he tells us that he was musing and thinking while he was lying down in the hay barn in the farm which was owned by his father, as young boys do. While he was thus thinking he realised he had to make a decision. The decision was whether he should stay at home and look after the farm, or whether he should go forth into the world and, as he puts it 'learn everything'.

He wrote some years later: 'It was a clear dark moonless night. There was a sweetness of the hay around me, and overhead the majesty of the night. I lay there looking up into the heavens, and somehow, all at once, the decision came, never to be questioned again. I will find out all that is possible for me to find out about the world, and this vast universe of ours. I will have, not the second best, but the best of all knowledge there is. And from that wonderful night when I lay on the 
hay thinking of this world and that infinite world up there, I have been a seeker after knowledge.'

The choice between being a farmer and finding out the meaning of life would not always be a difficult one to make. Whether he learned everything there was to know or not is doubtful, but it is reckoned that he spoke or understood around seventy languages or dialects by the time he died. He corresponded with Prime Ministers, was a friend of Longfellow, met Leo Tolstoy (along with millions of others), and contributed greatly to the growing field of ethnography, then in its infancy. His knowledge of and friendship with Henryk Sienkiewicz was entirely a matter of chance.

He happened to be on a streetcar, or bus, in Washington in the summer of 1887, when he spotted a man reading a Polish newspaper. Curtin was very direct in his manner, not something that always works with an Irish person. This he discovered later when he was collecting stories on the Blasket Islands and tempted a man with a bottle of whiskey. The man quickly told him that he would drink the whiskey first and tell the stories later. In this case, however, the Polish person with the newspaper informed him he was reading a story by Henryk Sienkiewicz which was being serialised, and after some cajoling from the persistent Curtin promised him he would send him back numbers of the newspaper. Curtin was so impressed with the story that he immediately ordered the trilogy With Fire and Sword, The Deluge and Pan Michael from Poland, and quickly made up his mind that he would translate them. The money he received from these translations, and from others by Sienkiewicz, allowed him to travel the world and to indulge his passion for tales, myths and legends. We might then say that the writings of a Polish author enabled the first proper collector of Irish folktales to do his work in the five trips that he made to Ireland, and the three substantial collections that he subsequently published.

His translation of Quo Vadis into English was published in 1897. We do know that he translated constantly, even while travelling by train, and it is almost certain that some of it was translated while he was in Ireland. This was not the first translation of the novel, but a chance meeting in a hotel in Switzerland in the same year forged a friendship between him and the author that lasted until Curtin's death in 1906. As a result of this friendship, Sienkiewicz gave Curtin the sole authority to translate his works from Polish into English, and his translation of Quo Vadis remained the classic translation for quite a number of years.

There was some controversy over the translations of his novels, and initially Sienkiewicz did not make much dosh or even lucre from them. In a notice in The New York Times dated April 10, 1900, he wrote: 'Having concluded with you an agreement concerning my novels translated by M. Jeremiah Curtin, and published by your house, I have the honour to declare, that the publication of these novels by other publishers (and translators), would be done against my will 
and interest.' In fact, there is an edition of Quo Vadis published in 2005, which gives equal weight on the title page to Sienkiewicz and to Curtin! It has been said that Curtin knew very little Polish when he first embarked on his translations, but used his work as a way to learn the language as he was making slow progress through the text.

He did indeed have an unorthodox way of learning languages, learning Finnish by translating 'The Gospel According to John' and by comparing it with the proper Finnish version. No doubt 'The Gospel According to John' would give anybody a very strange version of the Finnish language, as the Finns are not noted for their cleavage to Middle Eastern mysticism, but it certainly gave him a leg over into the language. There is also a debate about his full mental competence in Irish, but there is no doubt that he had enough of the language to accurately collect folk tales and to conduct his normal business in the language, even in Kerry, where he did most of his work.

While we know that Curtin visited the West Cork Gaeltacht area, he did not collect any stories there. It would be a neat connection if we could claim that he was informed by Amhlaoibh Ó Loingsigh, or by any of the other storytellers that debated the Irish translation of Quo Vadis with Aindrias Ó Céileachair.

Unfortunately, we cannot make that claim. Nor can we claim that Ó Céileachair used Curtin's translation, the one with the imprimatur of Sienkiewicz himself. The translation used was one of The Wayfarer's Library, translated by J.C. Hogarth in a version republished in 1926. But all is not lost.

The shortened version which Ó Céileachair originally used was an abridged version of Curtin's, and much of this he incorporated into the final translation despite all the awkwardnesses of juggling two versions. It is an old cliché that travel broadens the mind; it is as true to say that travel in the mind broadens the imagination, as well as challenging the language. So, there is a long journey from Henryk Sienkiewicz's travels into the mind of ancient Rome and turning a vicious and genocidal Latin culture into a more civilised Polish, to an English version of this great book by an Irish-American linguist who himself collected stories and tales in Irish, to a learned priest who used the ingenuity of his own people, and particularly the native knowledge of a great storyteller, to fashion one of the finest translations that has been done into modern Irish. I am not sure what Sienkiewicz would have made of it, but I am sure he would have been very pleased.

University College Cork, Ireland 


\section{References}

Uí Laighléis, G., 2007, ‘An Gúm: The Early Years’, in: Mac Mathúna, S. \& A. Ó Corráin, eds.; M. Fomin, assistant ed., Celtic Literatures in the Twentieth Century, Moscow: Languages of Slavonic Culture, 199-216.

Ó Céileachair, A., An tA., 1936, Henryk Sienkiewicz. Quo Vadis, do chuir i $n$ Gaedhlig, Baile Átha Cliath: Oifig Díolta Foillseacháin Rialtais.

McKenna, L., 1935, Foclóir Béarla agus Gaeilge. English-Irish Dictionary, Baile Átha Cliath: Oifig Díolta Foillseacháin Rialtais.

Ó Cuív, B., 1944, The Irish of West Muskerry, Co. Cork: a Phonetic Study, Dublin: DIAS.

Ó Cróinín, D., ed., 1971, Scéalaíocht Amhlaoibh Í Luínse, Béaloideas 35-36 (1967-68). 